\title{
Influence of Mineralogy and Geological Setting on Trace Metal Concentration within Subtropical Weathered Profiles, Bells Creek Catchment, Queensland, Australia ${ }^{1}$
}

\author{
Tania Liaghati, ${ }^{2,3}$ Micaela Preda, ${ }^{4}$ and Malcolm Cox ${ }^{4}$
}

\begin{abstract}
The effects of mineralogy and geological setting on trace metal concentration and distribution within six weathered profiles developed sandstone and mudstone was assessed. Primary minerals occurring in the weathered profiles are quartz, plagioclase, and K-feldspar. Kaolinite is the most dominant secondary mineral followed by mixed layers of smectite-illite, illite, hematite, siderite, and occasional calcite. Metal concentrations within fresh and weathered samples were investigated by two methods of digestions: HF-based digestion and aqua regia. Results revealed that $\mathrm{V}$ and $\mathrm{Cr}$ are largely present in the primary aluminosilicate matrix and are not easily available to the environment; however, $\mathrm{Cu}, \mathrm{Zn}$, and $\mathrm{Pb}$ are present in extractable forms and readily leached. Iron occurs in both primary minerals and insoluble secondary minerals such as hematite. The mineralogical study also showed that drill hole material with more clay minerals tends to contain higher metal concentrations, demonstrating that mineral composition is the major control over trace metal content. Spearman's rank correlation matrix also confirmed the role of mineralogy on trace metal concentration (e.g., $\mathrm{V}$ and $\mathrm{Cr}$ correlated with kaolinite and $\mathrm{Pb}$ correlated well with mixed layers of illite-smectite). Effect of geological setting on trace metal concentration was assessed by examining the geomorphological location of drill holes with respect to paleochannels, surface topography, and water table position. Results revealed that depth of burial of the weathered profile does not have an important effect on weathering and trace metal composition of samples. However, samples located on flat terrain and with shallow water table are more prone to leach metals. Factors controlling degree of chemical weathering and subsequent trace metal distribution are summarized in order of importance: mineralogy $>$ geological setting (topography and parent rock type) $>$ water table depth $>$ depth of profile burial.
\end{abstract}

Chemical weathering of rocks is one of the major processes that modify the earth's surface and is one of the key processes contri-

\footnotetext{
${ }^{1}$ Manuscript accepted 8 August 2004.

${ }^{2}$ School of Earth and Geographical Sciences, The University of Western Australia, Crawley, Western Australia, Australia.

${ }^{3}$ Corresponding author (phone: +61-7-3864 4185; fax: +61-7-3864 1535; e-mail: liaghati@cyllene.uwa.edu .au).

42 George Street, GPO Box 2434, Brisbane, Queensland 4001, Australia.
}

Pacific Science (2005), vol. 59, no. 3:421-438

(C) 2005 by University of Hawai'i Press

All rights reserved buting to the geochemical cycling of elements (Berner and Berner 1996). The effect of geological setting (e.g., parent rock type and topography), climate, and position of water table on chemical weathering of rocks is well documented (e.g., Jenny 1941, Loughnan 1969, Summerfield 1991, Macias and Chesworth 1992, Thomas 1994, Hill et al. 2000, Taylor and Eggleton 2001). For example, the subtropical climate of southeastern Queensland is a paramount factor in chemical weathering throughout the study area, as it readily produced highly weathered profiles such as those beneath the Tertiary land surfaces, which have undergone deeper weathering and induration than the interfluves (Grimes et al. 1986). In addition, by controlling weathering 
processes, topography can also influence the trace metal composition of both weathered bedrock and the underlying layers (Boggs 1995).

The mobilization and redistribution of trace metals during weathering are substantially affected by various processes such as dissolution of primary minerals and formation of secondary phases. Other factors that are important are $\mathrm{pH}$ and $\mathrm{Eh}$ conditions (e.g., Harris and Adams 1966, Chesworth et al. 1981, Cramer and Nesbitt 1983), soil texture (Richards et al. 2000), biological activities (Welch and McPhail 2003), and amount of organic matter (Kaschl et al. 2002, Udom et al. 2004). During weathering of crystalline rocks, primary mineral phases are partly dissolved, and hydrolysis and hydration take place. Secondary minerals such as illite and smectite are commonly the earliest to be formed, followed by halloysite and kaolinite. In the final stage, as leaching intensifies, partial desilicification occurs and kaolinite is converted to gibbsite. Feldspars, for example, often weather directly to an amorphous phase (Fields and Swindale 1954), then to kaolinite (McCaleb 1959, Exley 1976), and ultimately to gibbsite or boehmite (Helgeson et al. 1969, Parham 1969, Lodding 1972).

Reported studies investigating the roles of mineralogy, topography, and parent material on the trace metal concentration in sedimentary weathered profiles are limited due to either the lesser abundance of these rocks (only $5 \%$ of earth crust [Carroll 1970]) or their limited economic value. The aim of this study was therefore to investigate the extent to which mineral composition, topography, and parent material control trace metal distribution within sedimentary weathered profiles occurring in a subtropical setting. This investigation also increased our understanding of weathering mechanisms and trace metal distribution/mobility. In addition, although some of the profiles are present near the land surface, others are buried under thick layers of young unconsolidated sediments; the effect of this aspect of the setting on weathering and trace metal contents of the samples was therefore investigated. Stratigraphic and hydrogeological drilling in Bells
Creek catchment, southeastern Queensland (Figure 1) provided the opportunity to investigate several types of buried and exposed weathered profiles.

Digestion methods such as HF-based total digestion and aqua regia (partial digestion) are used to determine the amount of heavy metals potentially available in total rock in comparison with the same metals present in extractable forms. Such comparisons can be of importance to the environmental assessment of areas under development pressure, because studies of trace metals in soil typically represent bulk concentrations rather than comparisons between total and extractable metal concentrations.

\section{Study Area}

GEOMORPHIC FEATURES OF THE STUDY AREA. The Bells Creek catchment is predominately low lying (typically with relief of $<10 \mathrm{~m}$ ) and covers an area of $100 \mathrm{~km}^{2}$. It is located about $80 \mathrm{~km}$ north of Brisbane and is within the northern section of the Pumicestone region (Figure 1). The maximum elevation of the coastal plain in this catchment is around $55 \mathrm{~m}$ above sea level in the bedrock hills to the west; the central alluvial plain is less than $20 \mathrm{~m}$, and in the eastern strip the elevation is less than $5 \mathrm{~m}$ (Department of Natural Resources and Mines, unpubl. data).

Climatically, Bells Creek catchment is typical of southeast Queensland, which is subtropical with hot, wet summers and mild, dry winters. Mean rainfall over the 5 -yr period (1998-2003) varies from $1,340 \mathrm{~mm} / \mathrm{yr}$ in the south of the catchment to $1,580 \mathrm{~mm} /$ $\mathrm{yr}$ in the north. Mean daily temperatures range from 15 to $30^{\circ} \mathrm{C}$ in summer and 9 to $20^{\circ} \mathrm{C}$ in winter. Within the region there is a wide range of land-use practices including pine plantation, sugarcane, and horticulture; Melaleuca bush land is common along drainage lines, and mangrove forests are well developed along catchments and estuaries. The current land use in the catchment is predominantly pine plantation.

geological Setting. The Pumicestone region is part of an intracratonic basin, which accommodated a large fluvial system during 


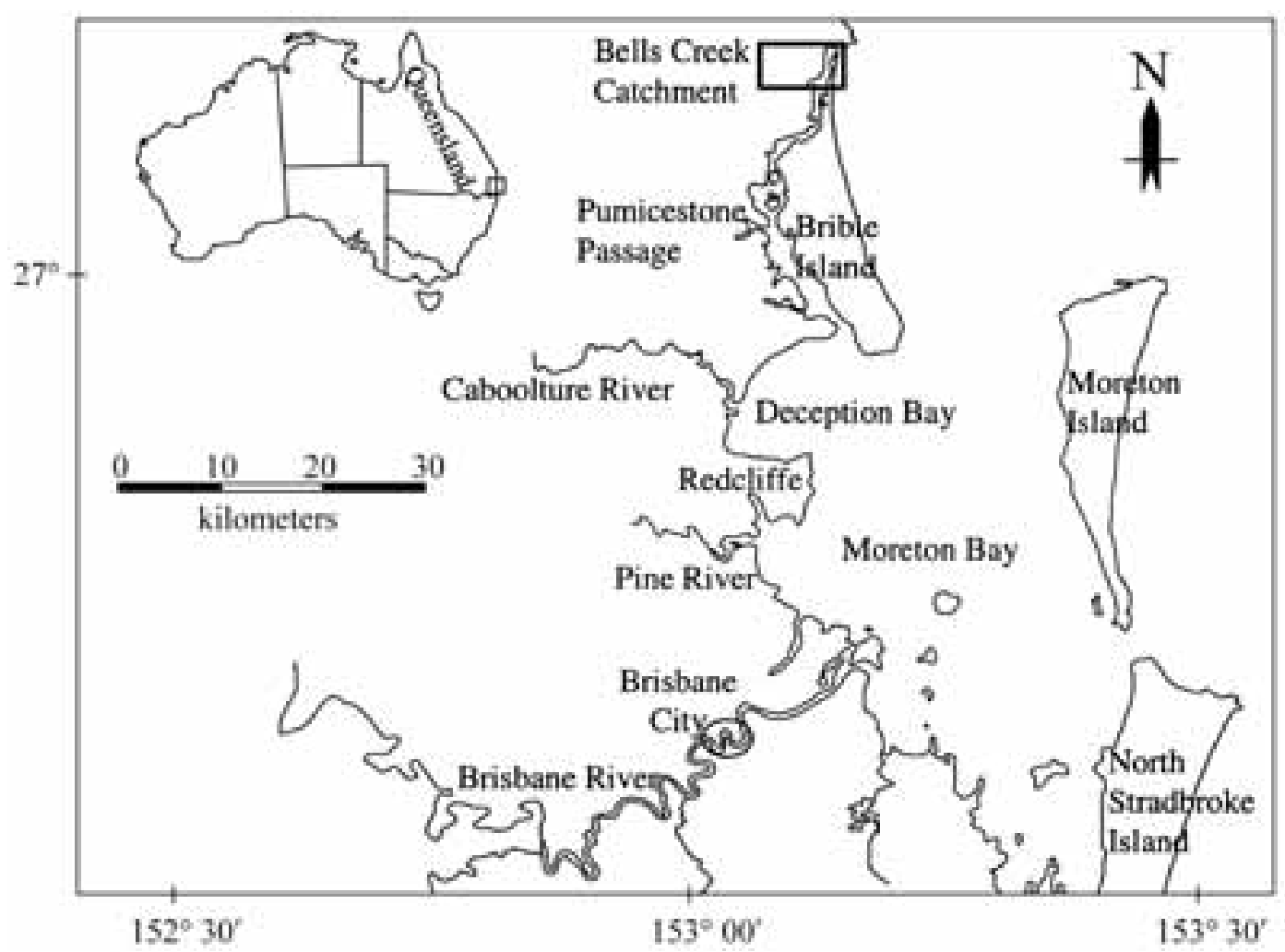

Figure 1. Location of the study area (rectangle at top of map) in relation to Pumicestone region and Moreton Bay in southeastern Queensland.

the early to middle Mesozoic (Cranfield 1983, Murphy et al. 1987). A variety of pre-existing, largely volcanic rocks have been eroded and supplied the fluvial system with material that was eventually incorporated in the Landsborough Sandstone, which is the only rock exposed in the catchment. This formation, which today represents the bedrock of the region, consists of quartzo-feldspathic sandstone with lithic fragments of volcanic origin and layers of shale, conglomerate, mudstone, and coal (e.g., Murphy et al. 1987). The sandstone consists mainly of quartz, plagioclase, occasional muscovite, and variable amounts of minerals of volcanic origin (mafic and titaniferous minerals, and glass) (Hawkins 1983). The most abundant weathering products are kaolinite and hematite (Preda and Cox 2002, Ezzy et al. 2003).

During low sea level conditions of the
Pleistocene period ( $\sim \mathrm{Ma}$ ), the eastern Australian continental shelf was exposed and incised by river systems. Subsequent rise in sea level led to the drowning of river channels and development of estuaries and coastal plains. In southeast Queensland, the current interglacial high stand was reached about 6,500 yr ago (Williams et al. 1998) when sea level was approximately $1.0 \mathrm{~m}$ higher than the present day; after 3,000 years B.P. the sea level in the Pumicestone region appears to have fallen to its current position (Flood 1981, Lester et al. 2000).

The heterogeneous character of the bedrock formation and the lability of the sandstone have led to the development of thick weathering profiles clearly due to exposure since the Pleistocene (Ezzy et al. 2002). The Bells Creek catchment is situated on the narrow coastal floodplain on Quaternary-age 
sedimentary material and outcropping Landsborough Sandstone bedrock. During low sea level episodes, down cutting into the bedrock led to the development of depressions and channels that eventually infilled with sediments during stages of higher sea level (Ezzy and Cox 2003). Recent investigations using ground-penetrating radar enabled the identification and visualization of the deeper coastal sequences and their depositional environment. Ezzy et al. (2003) investigated over 30 north-south and east-west groundpenetrating radar profiles revealing that the sand-rich alluvial channels are typically 5 to $8 \mathrm{~m}$ thick, with widths of between 50 and $200 \mathrm{~m}$. In areas where coarse-grained paleochannel sand horizons occurred in the upper weathered bedrock horizon, penetration was up to $5 \mathrm{~m}$ and bedding characteristics and channel morphologies could be interpreted. The associated drilling program confirmed the complex sedimentary architecture of the area and also enabled sampling of a number of buried weathered bedrock profiles.

\section{MATERIALS AND METHODS}

\section{Sampling Strategy}

The samples analyzed in this study were obtained by rotary drilling and consist of weathered and fresh parent material (Table 1, Figure 2). Drill cores were subsampled,

TABLE 1

Sample Locations: Depth and Characteristics

\begin{tabular}{|c|c|c|}
\hline Sample & Depth (m) & Core Characteristics $^{a}$ \\
\hline $\begin{array}{l}\text { S1-1 } \\
\text { S1-2 } \\
\text { S1-3 } \\
\text { S1-4 } \\
\text { S1-5 }\end{array}$ & $\begin{array}{l}2-3 \\
4-5 \\
8-9 \\
12-13 \\
13-15\end{array}$ & $\begin{array}{l}\text { No alluvial cover, water table just below surface } \\
0-13 \text { m weathered bedrock } \\
>13 \text { m fresh mudstone } \\
\text { Nonchannel drill hole }\end{array}$ \\
\hline $\begin{array}{l}\text { B3-1 } \\
\text { B3-2 } \\
\text { B3-3 } \\
\text { B3-4 }\end{array}$ & $\begin{array}{l}14 \\
16 \\
18 \\
20\end{array}$ & $\begin{array}{l}0-14 \mathrm{~m} \text { fluvial channel sands } \\
14-20 \mathrm{~m} \text { weathered material } \\
>20 \mathrm{~m} \text { fresh sandstone } \\
\text { Channel drill hole }\end{array}$ \\
\hline $\begin{array}{l}\text { B7-1 } \\
\text { B7-2 } \\
\text { B7-3 } \\
\text { B7-4 }\end{array}$ & $\begin{array}{l}8-8.5 \\
8.5-9 \\
9-9.5 \\
9.5-10\end{array}$ & $\begin{array}{l}0-7 \mathrm{~m} \text { fluvial channel sands and shallow water table } \\
7-9.5 \mathrm{~m} \text { weathered bedrock } \\
>9.5 \mathrm{~m} \text { fresh sandstone } \\
\text { Channel drill hole }\end{array}$ \\
\hline $\begin{array}{l}\text { L1-1 } \\
\text { L1-2 } \\
\text { L1-3 } \\
\text { L1-4 } \\
\text { L1-5 }\end{array}$ & $\begin{array}{l}6 \\
9 \\
12 \\
14 \\
16.4\end{array}$ & $\begin{array}{l}0-6 \mathrm{~m} \text { clay-rich alluvium, water table } 1 \mathrm{~m} \text { below surface } \\
6-16 \mathrm{~m} \text { weathered bedrock } \\
>16 \mathrm{~m} \text { fresh mudstone } \\
\text { Nonchannel drill hole }\end{array}$ \\
\hline $\begin{array}{l}\text { GB1-1 } \\
\text { GB1-2 } \\
\text { GB1-3 } \\
\text { GB1-4 } \\
\text { GB1-5 }\end{array}$ & $\begin{array}{l}16.5 \\
18 \\
20 \\
22 \\
26\end{array}$ & $\begin{array}{l}0-16.5 \mathrm{~m} \text { coastal sand, water table } \sim 3 \mathrm{~m} \\
16.5-25.5 \mathrm{~m} \text { weathered rock } \\
>25.5 \mathrm{~m} \text { fresh mudstone } \\
\text { Channel drill hole }\end{array}$ \\
\hline $\begin{array}{l}\text { H5-1 } \\
\text { H5-2 } \\
\text { H5-3 } \\
\text { H5-4 } \\
\text { H5-5 } \\
\text { H5-6 } \\
\text { H5-7 }\end{array}$ & $\begin{array}{l}3-4 \\
4-5 \\
5-6 \\
8-9 \\
10-11 \\
12-13 \\
13-14\end{array}$ & $\begin{array}{l}0-3 \mathrm{~m} \text { fine-grained clayey sand } \\
3-13 \mathrm{~m} \text { weathered bedrock } \\
>13 \mathrm{~m} \text { fresh mudstone } \\
\text { Channel drill hole }\end{array}$ \\
\hline
\end{tabular}

${ }^{a}$ Data taken from T. R. Ezzy, M.E.C., J. O’Rourke, and G. J. Huftile, unpubl. data. 


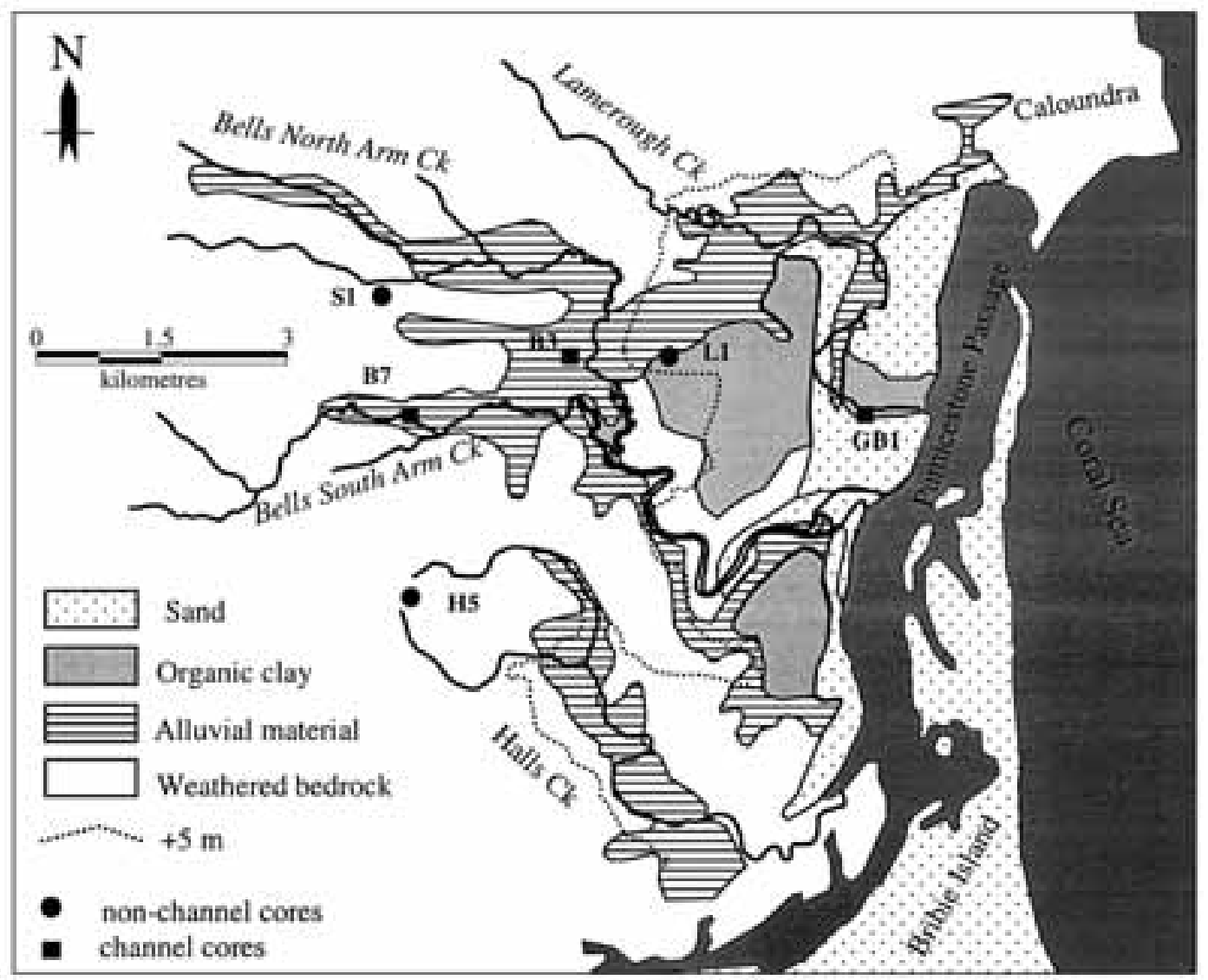

FIGURE 2. Core locations with respect to surficial material (after NSR Environmental Consultants 1999).

dried at $80^{\circ} \mathrm{C}$ for $24 \mathrm{hr}$, and comminuted with porcelain mortar and pestle. The drill holes are located on the main sedimentary rocks of the area (sandstone and mudstone) and also provided evidence on the role of the setting on weathering. Based on a concurrent study (T. R. Ezzy, M.E.C., J. O’Rourke, and G. J. Huftile, unpubl. data) of the stratigraphy of the area, it was confirmed that the material analyzed here has been weathered in situ and is not transported.

Drill holes studied here (T. R. Ezzy, M.E.C., J. O'Rourke, and G. J. Huftile, unpubl. data) can be categorized as being within (a) channel materials on top of Mesozoic sandstone (B3 and B7), (b) channel materials on top of Mesozoic mudstone (GB1), and (c) into thin $(\sim 2-3 \mathrm{~m})$ alluvium on top of Meso- zoic mudstone (S1, L1, and H5). These drill holes are shown in Figure 2.

\section{Analytical Methods}

To measure cations adsorbed by clays, organic matter, carbonates, and oxides, the samples were digested in concentrated aqua regia $\left(1 \mathrm{HNO}_{3}: 3 \mathrm{HCl}\right)$ following a procedure recommended by the International Organization for Standardization (ISO 1995). Samples were oven dried overnight at $100^{\circ} \mathrm{C}$ and $1 \mathrm{~g}$ was mixed with $1 \mathrm{ml} \mathrm{HNO}_{3}$ and $3 \mathrm{ml} \mathrm{HCl}$ and digested in a water bath at $95^{\circ} \mathrm{C}$ for $4 \mathrm{hr}$. The digests were quantified using an inductively coupled plasma optional emission spectrometer (ICP-OES) (Varian Liberty 200). The trace and minor metals analyzed 
were $\mathrm{V}, \mathrm{Cr}, \mathrm{Co}, \mathrm{Ni}, \mathrm{Cu}, \mathrm{Zn}, \mathrm{Pb}, \mathrm{Fe}, \mathrm{Mn}$, and Al.

To determine the total trace metal content (V, Cr, Co, Ni, Cu, Zn, and $\mathrm{Pb}$ ), $100 \mathrm{mg}$ of total sample was digested by $2.5 \mathrm{ml}$ of $\mathrm{HF}$ and $5 \mathrm{~mL}$ of $\mathrm{HNO}_{3}$ following a procedure described in Eggins et al. (1997). Samples were analyzed on an inductively coupled plasma mass spectrometer (ICP-MS) (Fisons PQ2+ Plasmaquad). This method was used also to determine concentrations of trace elements contained in silicate structures as a comparison with those that are more easily extractable and readily available to the environment.

The mineral composition of weathered and fresh bedrock was determined using $\mathrm{X}$ ray diffraction and a diffractometer (Philips PW 1050) equipped with a cobalt anode. Nonoriented powder samples were used to obtain total composition; oriented specimens were prepared for clay identification. The quantification of mineral phases was assisted by SIROQUANT (quantification program that expresses the composition of crystalline material within a sample in percentage of dry weight), which provides quantitative analyses of mineral phases based on the principle of Rietveld analysis (pattern synthesis). An ideal $\mathrm{X}$-ray diffraction pattern is synthesized from basic crystal structure data for each mineral in the sample. These synthesized patterns are added and fitted by a least squares refinement to the sample pattern. The quantification of the experimental $\mathrm{X}$-ray diffraction trace is thus indirectly performed by quantifying the synthesized pattern. There is rarely a perfect fit between a calculated (synthesized) pattern and the observed (experimental) one; this imperfect fit results in errors in the quantification of each mineral phase. For the current investigation, an approximate phase error of $1 \%$ is common to most mineral phases identified. The errors are mainly based on the goodness of fit between the synthesized Xray diffraction pattern and the experimental one. Larger errors were recorded for phases present in quantities larger than 30\%. Errors of up to $3 \%$ have been reported for Rietveld analysis of similar estuarine sediments (Preda and Cox 2004) and artificial mixes of sandstones (Hillier 2000).

\section{Statistical Analysis}

Correlation indices were calculated to determine the relationship between metal concentrations and potential inorganic scavengers (e.g., clay minerals, $\mathrm{Fe}$ and $\mathrm{Mn}$ oxides) that influence metal mobility and distribution within weathered material. Geochemical data such as produced in this study are not normally distributed, so Spearman's rank correlation was used because this method is more appropriate than a simple linear correlation (e.g., Pearson). Spearman's correlation matrix was generated using the statistical package SPSS v.10.

\section{Quality Control Procedures}

The precision and recovery level of the analytical procedure for acid digestion (aqua regia) and metal determination by ICP-OES were tested using the marine sediment reference standard PACS-2 (National Research Council Canada). This is a certified reference material (CRM) for total digestion, because CRM was not available for extractable method using aqua regia. Recoveries of most metals from the reference material were $>60 \%$, except for $\mathrm{V}, \mathrm{Cr}, \mathrm{Al}$, and $\mathrm{Mn}$ (Table 2). Vanadium and $\mathrm{Cr}$ are refractory metals, which strongly adsorb to siliceous materials; aluminum is part of the aluminosilicate matrix and the aqua regia digestion method is not robust enough to extract these metals. A low recovery percentage for $\mathrm{Cr}$ and $\mathrm{Al}$ had also been recorded by previous workers using a similar digestion method (Cook et al. 1997, Tam and Yao 1998). Means and standard deviations of the replicate samples were calculated. A comparison between the standard deviation of certified samples and replicate samples in this study revealed that repeatability generally had a relative standard deviation of $<5 \%$ even when recoveries were low (Table 2).

For quality assessment of the HF-based digestion, the standard BHVO-1 was analyzed. The results are shown in Table 3 along with relative standard deviation obtained for this standard in the Advanced Centre for Queensland University Isotope Research Excellence 
TABLE 2

Evaluation of Analytical Procedure Using Aqua Regia Digestion

\begin{tabular}{lcccc}
\hline \hline Element & Certified $^{a}(\mathrm{mg} / \mathrm{kg})$ & Found $^{b}(\mathrm{mg} / \mathrm{kg})$ & Recovery $(\%)$ & ${\text { Precision }(\% \mathrm{RSD})^{c}}^{c}$ \\
\hline $\mathrm{V}$ & $133 \pm 5$ & $62 \pm 1.7$ & 46.6 & 3 \\
$\mathrm{Cr}$ & $90.7 \pm 4.6$ & $42 \pm 1.2$ & 46.3 & 3 \\
$\mathrm{Mo}$ & $5.43 \pm 0.28$ & $3.4 \pm 0.4$ & 62 & 12 \\
$\mathrm{Co}$ & $11.5 \pm 0.3$ & $8.2 \pm 0.3$ & 71 & 4 \\
$\mathrm{Ni}$ & $39.5 \pm 2.3$ & $25 \pm 0.7$ & 63 & 2 \\
$\mathrm{Cu}$ & $310 \pm 12$ & $349 \pm 6$ & 93 & 2 \\
$\mathrm{Zn}$ & $364 \pm 23$ & $166 \pm 8$ & 95 & 4 \\
$\mathrm{~Pb}$ & $183 \pm 8$ & $21 \pm 0.5$ & 91 & 2 \\
$\mathrm{As}$ & $26.2 \pm 1.5$ & $27,628 \pm 828$ & 80 & 3 \\
$\mathrm{Fe}$ & $40,900 \pm 6,000$ & $208 \pm 6$ & 68 & 3 \\
$\mathrm{Mn}$ & $440 \pm 19$ & $13,385 \pm 534$ & 47.3 & 4 \\
$\mathrm{Al}$ & $66,200 \pm 3,200$ & & 20 & \\
\hline
\end{tabular}

a Certified Standard Reference Material, PACS-2 (harbor sediment, Canada).

${ }^{b}$ Mean and standard deviation of three replicated extractions are shown.

${ }^{c} \mathrm{RSD}$, relative standard deviation.

(ACQUIRE) laboratory. Both recovery level and precision were high, showing values of $94-100 \%$ and $<6 \%$, respectively.

\section{RESULTS}

\section{Trace and Minor Element Occurrence}

Based on concentrations of extractable cations the dominant trace metals measured are $\mathrm{Zn}, \mathrm{V}$, and $\mathrm{Cr}$, followed by $\mathrm{Cu}$ and $\mathrm{Pb}$ (Table 4). Elements such as $\mathrm{Co}$ and $\mathrm{Ni}$ generally occur below detection limit, except in core GB1, which has the highest metal content

TABLE 3

Evaluation of Analytical Procedure Using HF Digestion

\begin{tabular}{lrrrr}
\hline \hline Element & $\begin{array}{c}\text { Certified }^{a} \\
(\mathrm{mg} / \mathrm{kg})\end{array}$ & $\begin{array}{r}\text { Found }^{b} \\
(\mathrm{mg} / \mathrm{kg})\end{array}$ & $\begin{array}{c}\text { Recovery } \\
(\%)\end{array}$ & $\begin{array}{r}\text { Precision } \\
\text { (\% RSD) }\end{array}$ \\
\hline $\mathrm{V}$ & 317 & 305 & 96 & 1.4 \\
$\mathrm{Cr}$ & 289 & 291 & 100 & 2.7 \\
$\mathrm{Co}$ & 45 & 44.2 & 97 & 1.4 \\
$\mathrm{Ni}$ & 121 & 114 & 94 & 3.9 \\
$\mathrm{Cu}$ & 136 & 131 & 96 & 5.8 \\
$\mathrm{Zn}$ & 105 & 103 & 98 & 5.4 \\
$\mathrm{~Pb}$ & - & 1.95 & - & 3.8 \\
$\mathrm{Fe}$ & 85,541 & 84,291 & 98 & - \\
$\mathrm{Mn}$ & 1,301 & 1,290 & 99 & - \\
\hline
\end{tabular}

${ }^{a}$ Recommended values for basalt standard, BHVO-1, from Govindaraju (1994).

${ }^{b}$ Results found by ACQUIRE laboratory. for all the trace and minor elements. Trace elements such as $\mathrm{Co}, \mathrm{Ni}, \mathrm{Cu}$, and $\mathrm{Zn}$ are more abundant in fresh rock than its weathered counterparts, suggesting that they are being depleted by leaching (Liaghati, Preda and Cox, unpubl. data). Metals such as $\mathrm{V}$ and $\mathrm{Cr}$ occur in higher concentrations in the weathered materials probably due to their immobility and consequent accumulation. Concentration of iron in fresh rock ranges from 11,000 to $28,000 \mathrm{mg} / \mathrm{kg}$, but iron concentration fluctuates more in its weathered counterpart (300 to $119,000 \mathrm{mg} / \mathrm{kg}$ ) (Table 4). Minor elements such as $\mathrm{Al}$ and $\mathrm{Mn}$ behave in a different manner than Fe. Although $\mathrm{Al}$ occurs in similar concentrations in both fresh and weathered material, $\mathrm{Mn}$ concentration is substantially higher in fresh parent rock compared with the weathered layer. For example, in core S1, manganese concentration in fresh rock is 23 times greater than average concentration in its weathered counterpart (Table 4).

\section{Total versus Extractable Metal}

To clarify controls over trace metal behavior within weathered profiles, a comparison between total metal composition and the readily available extractable component was conducted (Table 5). Such a comparison also 
TABLE 4

Extractable Trace Element Contents (mg/kg) Determined by Aqua Regia for Selected Weathered Profiles

\begin{tabular}{lrrrrrrrrrr}
\hline \hline Sample & \multicolumn{1}{rl}{$\mathrm{V}$} & $\mathrm{Cr}$ & $\mathrm{Co}$ & $\mathrm{Ni}$ & $\mathrm{Cu}$ & $\mathrm{Zn}$ & $\mathrm{Pb}$ & $\mathrm{Fe}$ & $\mathrm{Mn}$ & $\mathrm{Al}$ \\
\hline S1-1 & 14 & 3 & $<1.2$ & $<1.5$ & 1 & 54 & $<3$ & 1,169 & 17 & 3,930 \\
S1-2 & 41 & 15 & $<1.2$ & $<1.5$ & 1 & 53 & 7 & 36,149 & 3 & 8,214 \\
S1-3 & 13 & 5 & 3 & 4 & 8 & 67 & 9 & 27,048 & 20 & 7,946 \\
S1-4 & 3 & 1 & 2 & 2 & 3 & 31 & 4 & 2,146 & 5 & 1,028 \\
S1-5 & $\mathbf{9}$ & $\mathbf{4}$ & $\mathbf{1 5}$ & $\mathbf{1 0}$ & $\mathbf{1 4}$ & $\mathbf{1 3 7}$ & $\mathbf{1 5}$ & $\mathbf{1 7 , 8 8 2}$ & $\mathbf{2 6 2}$ & $\mathbf{2 , 8 2 3}$ \\
B3-1 & 9 & 3 & 9 & 5 & 5 & 126 & 9 & 13,014 & 620 & 1,488 \\
B3-2 & 9 & 3 & 11 & 7 & 3 & 51 & 5 & 23,680 & 620 & 1,003 \\
B3-3 & 12 & 5 & 9 & 4 & 3 & 67 & 7 & 12,119 & 755 & 1,481 \\
B3-4 & $\mathbf{2 0}$ & $\mathbf{7}$ & $\mathbf{1 0}$ & $\mathbf{6}$ & $\mathbf{4}$ & $\mathbf{6 4}$ & 7 & $\mathbf{2 6 , 4 1 1}$ & $\mathbf{1 , 3 0 0}$ & $\mathbf{1 , 8 3 4}$ \\
L1-1 & 3 & 4 & $<1.2$ & $<1.5$ & 1 & 21 & 4 & 488 & 3 & 4,954 \\
L1-2 & 3 & 2 & $<1.2$ & $<1.5$ & 1 & 26 & $<3$ & 294 & 3 & 2,834 \\
L1-3 & 5 & 2 & $<1.2$ & $<1.5$ & 1 & 50 & $<3$ & 2,262 & 19 & 2,549 \\
L1-4 & 10 & 3 & 1.2 & $<1.5$ & 2 & 37 & 5 & 15,887 & 28 & 3,583 \\
L1-5 & $\mathbf{1 2}$ & $\mathbf{5}$ & $\mathbf{1 4}$ & $\mathbf{9}$ & $\mathbf{8}$ & $\mathbf{1 0 5}$ & $\mathbf{1 5}$ & $\mathbf{2 8 , 3 3 0}$ & $\mathbf{8 1 9}$ & $\mathbf{5 , 0 9 8}$ \\
GB1-1 & 4 & 5 & $<1.2$ & 2 & 1 & 61 & $<3$ & 822 & 8 & 2,312 \\
GB1-2 & 284 & 352 & 10 & 63 & 55 & 77 & 6 & 38,226 & 50 & 11,118 \\
GB1-3 & 201 & 475 & 24 & 116 & 54 & 95 & 4 & 119,736 & 65 & 16,461 \\
GB1-4 & 70 & 54 & 59 & 200 & 89 & 100 & $<3$ & 14,893 & 35 & 10,773 \\
GB1-5 & $\mathbf{9}$ & $\mathbf{2 7}$ & $\mathbf{1 9}$ & $\mathbf{4 6}$ & $\mathbf{1 0}$ & $\mathbf{1 1 1}$ & 7 & $\mathbf{1 5 , 6 9 4}$ & $\mathbf{6 9}$ & $\mathbf{7 , 6 6 9}$ \\
H5-1 & 34 & 10 & $<1.2$ & $<1.5$ & $<0.5$ & 43 & 6 & 22,285 & 5 & 10,863 \\
H5-2 & 28 & 7 & $<1.2$ & $<1.5$ & $<0.5$ & 37 & 12 & 15,498 & 2 & 7,981 \\
H5-3 & 36 & 8 & $<1.2$ & $<1.5$ & 0.84 & 26 & 14 & 23,157 & 4 & 9,557 \\
H5-4 & 28 & 5 & $<1.2$ & $<1.5$ & 2 & 47 & 6 & 30,741 & 18 & 5,579 \\
H5-5 & 19 & 6 & $<1.2$ & 1.5 & 3 & 56 & 8 & 23,208 & 57 & 10,526 \\
H5-6 & 30 & 7 & $<1.2$ & 1.5 & 5 & 138 & 32 & 29,802 & 40 & 10,715 \\
H5-7 & $\mathbf{9}$ & $\mathbf{6}$ & $\mathbf{2}$ & $\mathbf{3}$ & $\mathbf{8}$ & $\mathbf{6 0}$ & $\mathbf{1 5}$ & $\mathbf{1 1 , 2 9 6}$ & $\mathbf{6 0}$ & $\mathbf{1 0 , 5 9 9}$ \\
\hline
\end{tabular}

Note: Bold type indicates relatively fresh parent material.

TABLE 5

Comparison between Selected Extractable and Total Metal Concentrations for Selected Samples (mg/kg)

\begin{tabular}{lrrrrrrrrrrrrrr}
\hline \hline Samples & $\begin{array}{c}\mathrm{V} \\
(\mathrm{t})^{a}\end{array}$ & $\begin{array}{c}\mathrm{V} \\
(\mathrm{ex})^{b}\end{array}$ & $\begin{array}{r}\mathrm{Cr} \\
(\mathrm{t})\end{array}$ & $\begin{array}{c}\mathrm{Cr} \\
(\mathrm{ex})\end{array}$ & $\begin{array}{c}\mathrm{Zn} \\
(\mathrm{t})\end{array}$ & $\begin{array}{r}\mathrm{Zn} \\
(\mathrm{ex})\end{array}$ & $\begin{array}{r}\mathrm{Cu} \\
(\mathrm{t})\end{array}$ & $\begin{array}{r}\mathrm{Cu} \\
(\mathrm{ex})\end{array}$ & $\begin{array}{r}\mathrm{Pb} \\
(\mathrm{t})\end{array}$ & $\begin{array}{r}\mathrm{Pb} \\
(\mathrm{ex})\end{array}$ & $\begin{array}{r}\mathrm{Mn} \\
(\mathrm{t})\end{array}$ & $\begin{array}{r}\mathrm{Mn} \\
(\mathrm{ex})\end{array}$ & $\begin{array}{r}\mathrm{Fe} \\
(\mathrm{t})\end{array}$ & $\begin{array}{r}\mathrm{Fe} \\
(\mathrm{ex})\end{array}$ \\
\hline S1-1 & 23 & 14 & 14 & 3 & 54 & 32 & 1 & 1 & 3 & 3 & 26 & 17 & 4,500 & 1,169 \\
S1-2 & 75 & 41 & 42 & 15 & 53 & 11 & 1 & 1 & 12 & 8 & 38 & 3 & 71,300 & 36,149 \\
S1-3 & 67 & 13 & 30 & 5 & 67 & 38 & 9 & 9 & 13 & 10 & 20 & 20 & 53,000 & 27,048 \\
S1-4 & 18 & 3 & 8 & 1 & 32 & 14 & 7 & 3 & 6 & 4 & 5 & 5 & 5,400 & 2,146 \\
S1-5 & 53 & 9 & 29 & 4 & 138 & 117 & 15 & 14 & 17 & 15 & 309 & 262 & 36,000 & 17,882 \\
B3-1 & 43 & 9 & 37 & 3 & 126 & 103 & 5 & 5 & 13 & 9 & 651 & 620 & 24,000 & 13,014 \\
B3-2 & 22 & 9 & 10 & 3 & 52 & 34 & 3 & 3 & 7 & 5 & 578 & 550 & 35,500 & 23,680 \\
B3-3 & 38 & 12 & 25 & 5 & 67 & 46 & 4 & 3 & 9 & 7 & 814 & 755 & 18,400 & 12,119 \\
B3-4 & 43 & 20 & 20 & 7 & 64 & 49 & 4 & 4 & 10 & 7 & 1,274 & 1,200 & 41,300 & 26,411 \\
GB1-1 & 18 & 4 & 19 & 5 & 61 & 25 & 3 & 2 & 6 & 3 & 17 & 8 & 2,900 & 822 \\
GB1-2 & 381 & 284 & 725 & 352 & 78 & 69 & 63 & 56 & 17 & 6 & 122 & 50 & 73,000 & 38,226 \\
GB1-3 & 290 & 201 & 842 & 475 & 96 & 93 & 60 & 54 & 7 & 4 & 180 & 65 & 243,200 & 119,736 \\
GB1-4 & 360 & 70 & 277 & 53 & 100 & 95 & 86 & 84 & 6 & 3 & 177 & 35 & 50,300 & 14,893 \\
GB1-5 & 63 & 26 & 75 & 27 & 111 & 86 & 16 & 10 & 12 & 7 & 120 & 69 & 32,400 & 15,694 \\
\hline
\end{tabular}

${ }^{a}(\mathrm{t})$, total element content $(\mathrm{HF})$.

$b$ (ex), readily extractable element (aqua regia). 
TABLE 6

Mineralogy of Weathered and Fresh Rocks (\%) by X-Ray Diffraction Method

\begin{tabular}{|c|c|c|c|c|c|c|c|c|}
\hline Sample & Quartz & Feldspar & Kaolinite & Mixed Layer I/S & Illite & Hematite & Siderite & Calcite \\
\hline S1-1 & 78.9 & 0.7 & 18.9 & 1.5 & 0.0 & nd & nd & - \\
\hline S1-2 & 39.0 & 0.9 & 42.9 & 9.7 & 3.7 & 3.9 & nd & - \\
\hline S1-3 & 32.0 & 2.4 & 30.1 & 21.5 & 10.5 & 3.6 & nd & - \\
\hline S1-4 & 85.0 & 5.4 & 3.7 & 3.3 & 2.6 & nd & nd & - \\
\hline S1-5 & 64.8 & 6.9 & 17.2 & 6.0 & 3.5 & nd & 1.7 & - \\
\hline B3-1 & 55.8 & 16.2 & 12.8 & 8.3 & 2.7 & 1.1 & 3.0 & - \\
\hline B3-2 & 65.3 & 14.5 & 8.0 & 3.8 & 2.5 & 1.1 & 4.8 & - \\
\hline B3-3 & 62.2 & 15.2 & 10.7 & 4.2 & 3.5 & nd & 2.5 & 1.7 \\
\hline B3-4 & 57.0 & 16.3 & 11.4 & 5.3 & 3.9 & nd & 5.3 & 0.8 \\
\hline B7-1 & 72.8 & 6.7 & 16.5 & 1.9 & 2.1 & nd & nd & - \\
\hline B7-2 & 70.4 & 15.1 & 12.0 & 1.9 & 0.6 & nd & nd & - \\
\hline B7-3 & 79.6 & 15.1 & 5.3 & Traces & Traces & nd & nd & - \\
\hline B7-4 & 53.9 & 37.3 & 2.2 & 1.3 & 5.3 & nd & nd & - \\
\hline L1-1 & 82.7 & 1.1 & 15.6 & 0.0 & nd & 0.7 & nd & - \\
\hline L1-2 & 88.1 & 0.5 & 11.0 & nd & nd & 0.3 & nd & - \\
\hline L1-3 & 86.7 & 0.3 & 12.3 & nd & 0.1 & 0.7 & nd & - \\
\hline L1-4 & 82.3 & 0.8 & 13.8 & nd & 1.9 & 1.2 & nd & - \\
\hline L1-5 & 50.7 & 6.8 & 16.5 & 6.4 & 13.4 & 0.7 & 5.6 & - \\
\hline GB1-1 & 96.3 & 0.4 & 2.5 & nd & 0.1 & 0.7 & nd & - \\
\hline GB1-2 & 54.9 & 0.8 & 42.4 & nd & nd & 1.9 & nd & - \\
\hline GB1-3 & 19.4 & 1.0 & 68.6 & nd & 6.1 & 4.9 & nd & - \\
\hline GB1-4 & 2.6 & 15 & 80.2 & nd & nd & 2.2 & nd & - \\
\hline GB1-5 & 61.0 & 15.7 & 9.4 & 3.6 & 9.3 & 0.9 & nd & - \\
\hline H5-1 & 49.5 & 0.7 & 41.6 & 5.9 & nd & 2.4 & nd & - \\
\hline H5-2 & 55.9 & 1.0 & 31.2 & 9.5 & nd & 2.5 & nd & - \\
\hline H5-3 & 55.5 & 1.4 & 34.3 & 6.1 & nd & 2.6 & nd & - \\
\hline H5-4 & 76.7 & 1.1 & 14.9 & 4.2 & nd & 3.2 & nd & - \\
\hline H5-5 & 60.2 & 1.3 & 25.3 & 11.2 & nd & 2.0 & nd & - \\
\hline H5-6 & 68.9 & 1.5 & 21.9 & 4.1 & 2.7 & 0.9 & nd & - \\
\hline H5-7 & 50.8 & 2.8 & 25.0 & 16.0 & 3.5 & 1.7 & nd & - \\
\hline
\end{tabular}

Note: Bold type represents fresh rock. nd, not detected $(<0.5 \%$ for primary minerals and $<1 \%$ for clay minerals). - , no analysis.

helps assess the potential further release of such metals from weathered bedrock. Both methods of digestion (extractable and total) were applied for selected samples to compare the amount of trace elements contained in silicate structures with those weakly adsorbed and easily extractable. Fourteen samples were selected (four to five samples from three cores) to cover the whole range of values identified by aqua regia.

\section{Mineralogical Composition}

The primary minerals identified in the study area are quartz (2-96\%), plagioclase (1$32 \%$ ) and $\mathrm{K}$-feldspar, which occurs in only five samples (3-10\%); secondary minerals are kaolinite $(0-67 \%)$, mixed layers of smectite-illite (0-22\%), illite (0-14\%), hematite, goethite, siderite, and calcite (Table 6). Overall, parent rock silicates have been extensively replaced by clay minerals and $\mathrm{Fe}$ oxides (mainly hematite).

Spatial variation of mineralogical content was studied in cores S1, H5, and L1 (Figure 3). Cores $\mathrm{S} 1$ and $\mathrm{H} 5$ are mineralogically comparable, but core L1 is substantially different compared with other cores discussed earlier. The most abundant primary mineral is quartz, and the clay content decreases upward (Table 6, Figure 3). Other cores such as B7, $\mathrm{B} 3$, and GB1 clearly demonstrate a range of vertical variations within weathered profiles (Figure 4). 

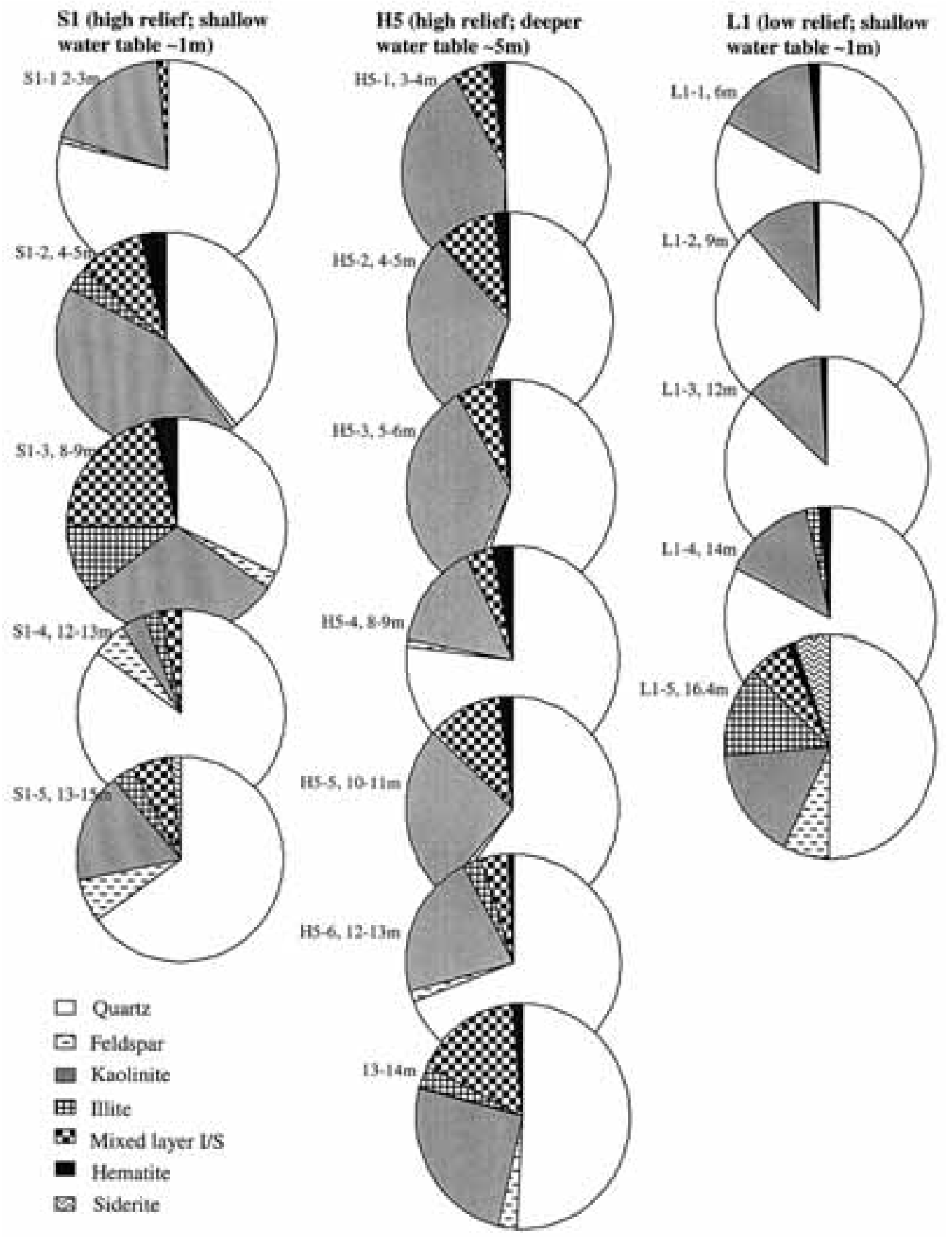

FIGURE 3. Spatial variations in mineralogy between bore holes developed on mudstone. S1 and H5 are both located on a higher relief. S1 is more leached compared with H5 due to its shallow water table. Although the water table occurrence in core L1 is similar to that in S1 (1 m below the surface), the degree of weathering and leaching in L1 is higher than in $\mathrm{S} 1$ because the former is located on a flat terrain. 

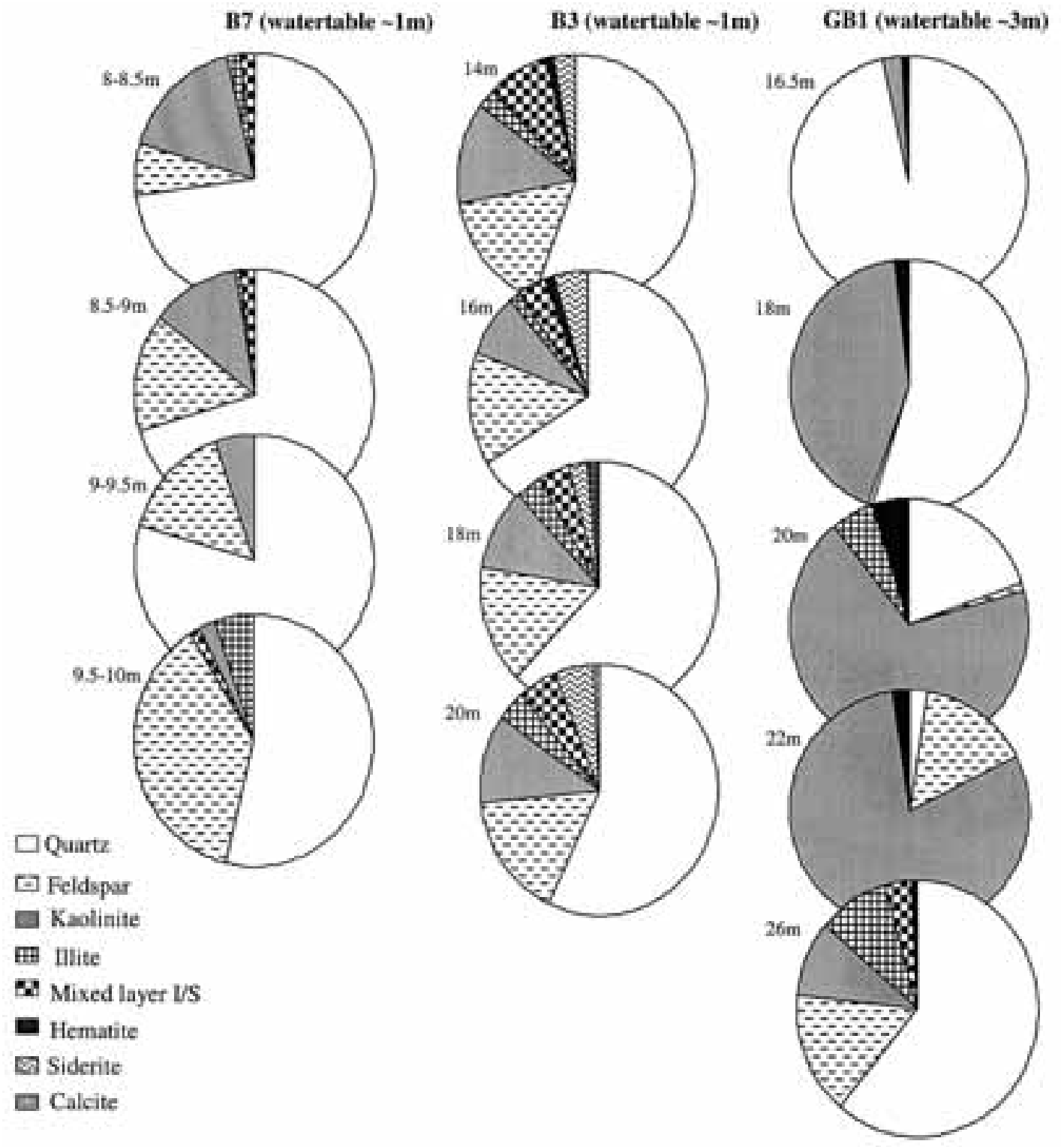

FIGURE 4. Vertical variations in mineralogy showing that deeper layers are fresher with higher primary mineral content. Both B7 and B3 are developed on sandstone bedrock, but GB1 shows a weathered profile within mudstonedominated bedrock. The higher clay amounts in GB1 compared with B7 and B3 show this difference between parent rocks.

\section{DISCUSSION}

\section{Relationship between Total and Extractable Components}

The lower values of extractable $\mathrm{V}$ and $\mathrm{Cr}$ content compared with total digestion indi- cate that they are part of the aluminosilicate matrix and from an environmental prospective are not readily releasable. Metals such as $\mathrm{Cu}, \mathrm{Zn}$, and $\mathrm{Pb}$, however, are mostly adsorbed to particles and easily leached and available to the environment. Manganese 
does not show consistent behavior and only has high extractability where its concentration is high (up to $95 \%$ recovery). Iron occurs in primary minerals (lithic fragments of volcanic origin have been reported by Cranfield [1983] and Hawkins [1983]) and as insoluble secondary iron phases such as hematite (Table 6). A comparison between total and extractable iron (Table 5) shows that its extractability varies between 30 and $65 \%$, suggesting that the remaining iron is in primary mineral structures and can undergo further release during weathering.

\section{Relationship between Mineralogy, Geological Setting, and Chemical Composition of Weathering Profiles}

Six distinctly different weathering profiles were identified at the top of the parent bedrock in Bells Creek catchment and vary in thickness between 10 and $26 \mathrm{~m}$. The study of mineral and chemical composition shows that the spatial variation of mineralogical content is controlled by topography and position of water table (Figure 3 ) and also relates to the composition of parent rock (Figure 4).

Drill holes S1 and H5 are both located in slightly undulating weathered bedrock hills and are mineralogically comparable, but core $\mathrm{L} 1$ is situated on a flat terrain. In profiles S1 and $\mathrm{H} 5$, the albite is the dominant plagioclase observed; its amount decreases upward, while the kaolinite content increases, indicative of intense weathering and leaching (e.g., Chamley 1989). Core S1 contains less cation-rich clays such as mixed layers and hematite at the top of the profile. Because these minerals are the main scavengers for trace elements, average trace metal content relative to parent material for core S1 is much lower compared with drill hole H5 (Figure 5). The differences could be related to the fact that in core S1 the water table (determined by groundpenetrating radar) was just below the surface, but in $\mathrm{H} 5$ it was located well below $5 \mathrm{~m}$. In drill hole L1 the water table occurred $1 \mathrm{~m}$ below the surface, and although the mudstone bedrock contains $36 \%$ clay minerals (Table 5 ) in the upper part of the profile the amount of clays substantially decreases (e.g., at $9 \mathrm{~m}$ depth L1-2 contains only $11 \%$ kaolinite). A comparison between metal contents of core $\mathrm{L} 1$ with $\mathrm{S} 1$ and $\mathrm{H} 5$ confirms that lower clay mineral content contributes to low metal content in core L1. In addition, comparisons between these three cores reveal that material located on flat terrain with a shallow water table (e.g., L1) weathers to a greater extent than cores located in undulating hills (Figure 3). Shallow groundwater is also associated with low concentrations of trace metals, suggesting that subsurface water flow is an important mobilizing factor (Figure 6).

Core B7 is comparable with B3 because samples taken from them occur 7-14 $\mathrm{m}$ below paleofluvial channels and have developed on sandstone. Mineralogical data show that B7 with a shallow water table is more weathered than B3 because it contains higher amount of quartz (up to $80 \%$ ) and only $6.6 \%$ of feldspars (Table 5). Core GB1 contains the most weathered material encountered and the compositions of the samples taken from this core clearly demonstrate the different phases of weathering and leaching operating in this system (Figure 4). The presence of higher feldspar content in GB1-5 (16\%) indicates a fresher rock, and the development of kaolinite from GB1-4 to GB1-3 suggests alteration of silicate minerals. From GB1-2 to GB1-1 the transition from weathered zone to completely leached zone is clearly illustrated (Figure 4). Core GB1 is the most suitable core for the study of vertical distribution of trace elements with regard to weathering and mineralogical content. In GB1-1 there is a substantial decrease in trace element contents due to extreme leaching compared with the other three samples from this core.

One of the initial assumptions was that the setting (i.e., nonchannel or channel) could have an influence on the weathering. The study shows that metal concentration of shallow profiles (e.g., S1) does not differ from that of profiles developed under thick layers of unconsolidated material (e.g., H5). It can therefore be concluded that the effect of depth of burial of the weathered profile is insignificant compared with mineralogy.

The presence of kaolinite in all the samples (up to 69\%) is indicative of intense 

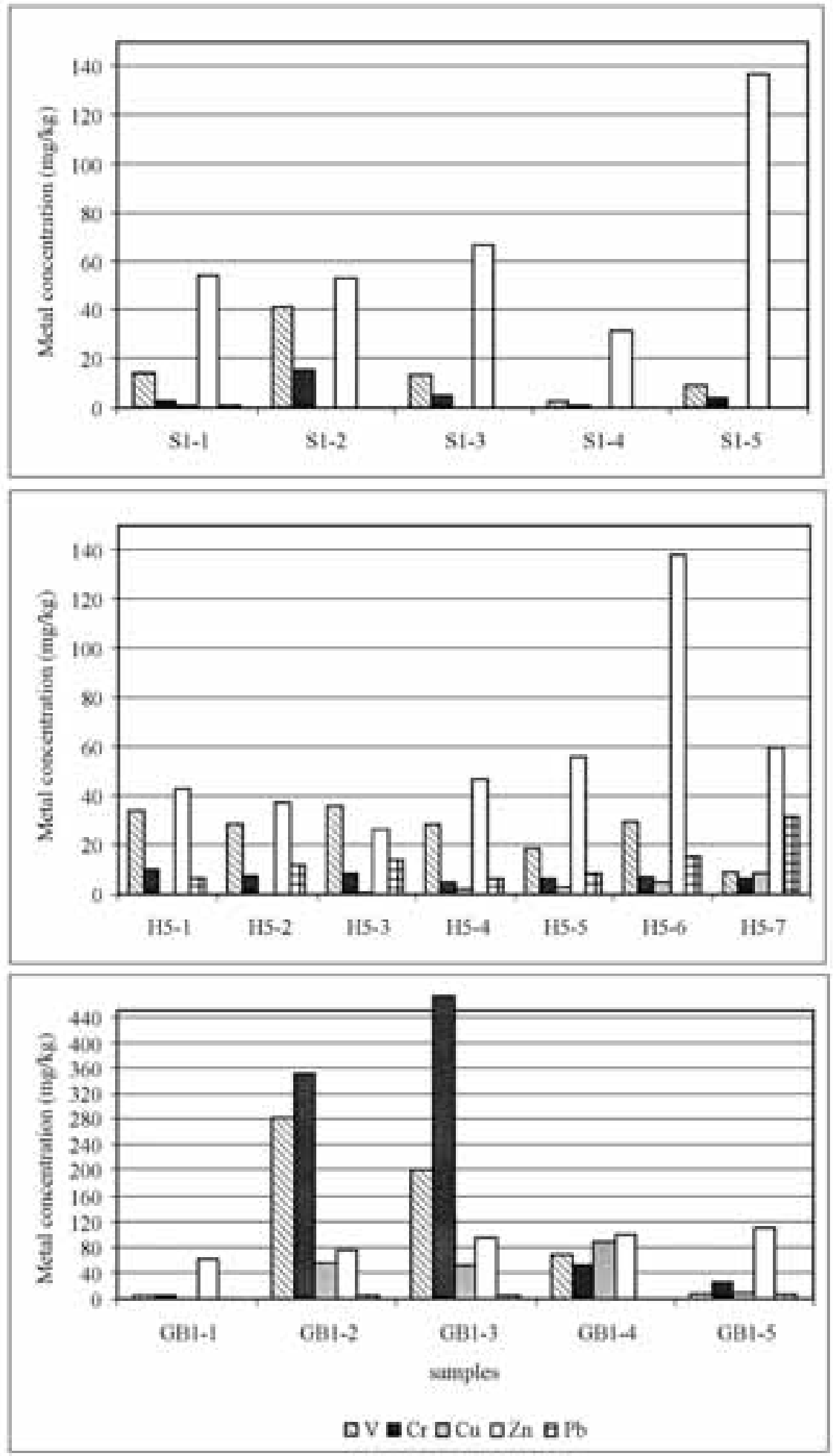

FigURE 5. Vertical variation of metal distribution with regard to mineralogy (Figures 3 and 4). 


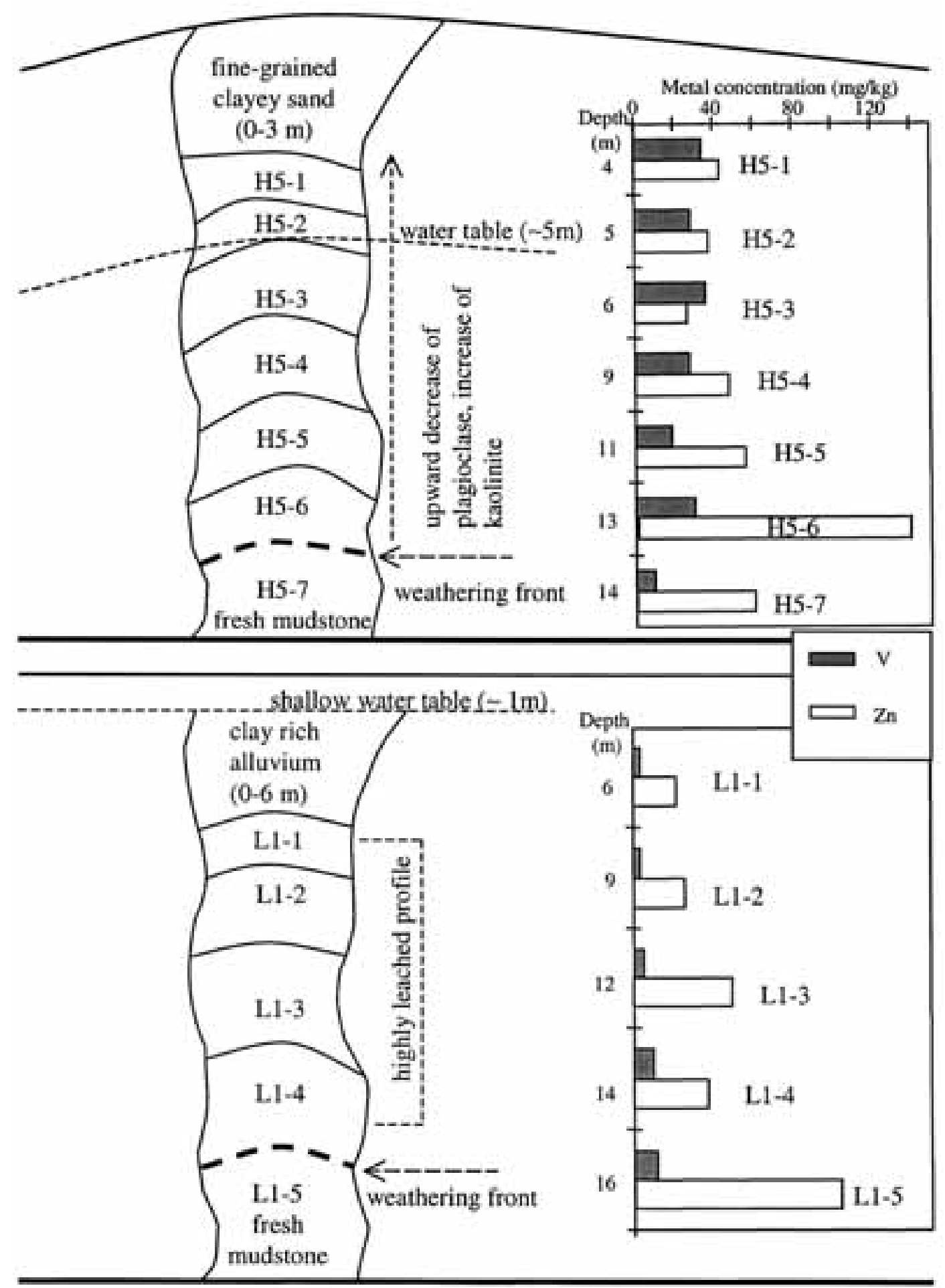

FIGURE 6. Schematic representation (not to scale) of effect of relief and water table position on two typical weathered profiles. Profile H5 is located on an undulating weathered hill with deeper water table and shows a limited degree of weathering. Profile L1 is located on a flat terrain with water table occurring $1 \mathrm{~m}$ below the surface. Metal distribution is shown to be related to degree of weathering. 
TABLE 7

Spearman's Rank Correlation Matrix for Weathered Material $(n=26)$

\begin{tabular}{|c|c|c|c|c|c|c|c|c|c|c|c|c|c|c|}
\hline & $\mathrm{V}$ & $\mathrm{Cr}$ & $\mathrm{Cu}$ & $\mathrm{Zn}$ & $\mathrm{Pb}$ & $\mathrm{Fe}$ & Mn & $\mathrm{Al}$ & Quartz & Feldspar & Kaolinite & Illite & $\begin{array}{l}\text { Mixed } \\
\text { Layer }\end{array}$ & Hematite \\
\hline V & 1.0 & & & & & & & & & & & & & \\
\hline $\mathrm{Cr}$ & 0.8 & 1.0 & & & & & & & & & & & & \\
\hline $\mathrm{Cu}$ & 0.2 & 0.3 & 1.0 & & & & & & & & & & & \\
\hline $\mathrm{Zn}$ & 0.2 & 0.3 & 0.8 & 1.0 & & & & & & & & & & \\
\hline $\mathrm{Pb}$ & 0.2 & 0.3 & 0.3 & 0.4 & 1.0 & & & & & & & & & \\
\hline $\mathrm{Fe}$ & 0.7 & 0.6 & 0.4 & 0.4 & 0.4 & 1.0 & & & & & & & & \\
\hline$M n$ & 0.0 & 0.1 & 0.7 & 0.7 & 0.3 & 0.3 & 1.0 & & & & & & & \\
\hline $\mathrm{Al}$ & 0.7 & 0.8 & 0.2 & 0.1 & 0.2 & 0.5 & -0.2 & 1.0 & & & & & & \\
\hline Quartz & -0.7 & -0.7 & -0.4 & -0.4 & -0.4 & -0.6 & -0.2 & -0.6 & 1.0 & & & & & \\
\hline Feldspar & -0.1 & 0.0 & 0.6 & 0.5 & 0.5 & 0.2 & 0.7 & -0.3 & -0.3 & 1.0 & & & & \\
\hline Kaolinite & 0.8 & 0.7 & 0.2 & 0.1 & 0.2 & 0.5 & -0.2 & 0.9 & -0.8 & -0.2 & 1.0 & & & \\
\hline Illite & -0.1 & 0.1 & 0.5 & 0.6 & 0.4 & 0.3 & 0.6 & -0.2 & -0.3 & 0.5 & -0.2 & 1.0 & & \\
\hline Mixed Layer & 0.2 & 0.1 & 0.0 & 0.2 & 0.8 & 0.3 & 0.2 & 0.1 & -0.5 & 0.4 & 0.3 & 0.3 & 1.0 & \\
\hline Hematite & 0.6 & 0.6 & 0.0 & -0.1 & 0.2 & 0.6 & -0.2 & 0.7 & -0.6 & -0.2 & 0.7 & -0.1 & 0.3 & 1.0 \\
\hline
\end{tabular}

Note: Bold type shows strong correlation. $0.60-1.00=$ strong correlation; $0.50-0.59=$ moderate; $0.40-0.49=$ weak; $0.00-$ $0.39=$ little or no association.

weathering. Although the intensity of weathering for almost all the profiles is intense to extreme (60-100\%) (unpubl. data), gibbsite, which is often associated with advanced weathering, was not found in any of the profiles. Gibbsite commonly occurs with kaolinite in tropical areas and is a major end product of weathering of aluminosilicate minerals. In some areas an abundance of moisture and good drainage contribute to formation of crystalline gibbsite (e.g., Evans 1992); in other regions, relatively higher elevation and more than $7,000 \mathrm{~mm} / \mathrm{yr}$ of precipitation (e.g., Islam et al. 2002) or deep weathering fronts (e.g., Calvert et al. 1980) create conditions favorable for forming a kaolinitegibbsite-goethite suite through weathering of feldspars. Gibbsite has not formed in the weathered profiles studied presumably due to insufficient moisture and drainage, because the study area is relatively low lying with an average yearly precipitation of only 1,400 $\mathrm{mm}$. However, traces of gibbsite could have been present but in quantities undetectable by $\mathrm{X}$-ray diffraction.

The mineralogical study revealed siderite and occasional calcite in cores S1, B3, and L1. In general, siderite occurrence is due to diagenetic processes under high temperature and pressure (Berner 1971, Mozley and Wer- sin 1992, Taylor 1998, Uysal et al. 2000); in the case in the Bells Creek catchment, it is more likely that siderite and calcite have both precipitated in rock fractures from carbonaterich pore water. The scarce occurrence of carbonates did not allow for speculation on the influence of these minerals on metal distribution/mobility.

\section{Correlations between Mineralogy and Trace Metal Distribution}

Spearman's rank correlation matrix enabled the identification of relationships between metals and potential inorganic scavengers influencing metal mobility and distribution within weathered material (Table 7). Based on the correlation matrix, concentration of $\mathrm{V}$ and $\mathrm{Cr}$ is predominantly controlled by kaolinite. However, the primary control over $\mathrm{Cu}$ and $\mathrm{Zn}$ concentration is $\mathrm{Mn}$, followed by illite; $\mathrm{Pb}$ correlated only with mixed layers of illite-smectite.

A comparison between pie graphs (Figures 3 and 4) representing mineralogy of the drill holes with trace metal concentrations (Figure 5) confirmed the interpretation based on the correlation matrix. Although the concentration of metals such as $\mathrm{V}$ and $\mathrm{Cr}$ is primarily controlled by kaolinite, other scavengers 
such as $\mathrm{Fe}, \mathrm{Al}$, and hematite also influence their occurrence and distribution. As shown by Figures 4 and 5, highest concentration of $\mathrm{V}$ and $\mathrm{Cr}$ occurs in core GB1-3 with almost $70 \%$ kaolinite content and 5\% hematite (the highest in this core). This finding demonstrates that although kaolinite concentration was up to $80 \%$ in GB1-4, $\mathrm{V}$ and $\mathrm{Cr}$ concentrations were lower than in GB1-4 perhaps due to high concentration of feldspars in GB1-4. For elements such as $\mathrm{Pb}$ the dominant influence of mixed layers of illitesmectite as scavenger can be observed in Figures 3 and 5 . These figures show that highest concentration of $\mathrm{Pb}(32 \mathrm{mg} / \mathrm{kg})$ occurs at H1-7, with the highest mixed layer content of $16 \%$. The effect of clay minerals on $\mathrm{Zn}$ is not obvious from Figures 3-5 because concentration of this element is predominantly correlated with Mn concentrations (Table 7).

Overall, profiles with lower abundances of secondary minerals contain lower concentrations of metals, as clay minerals and hematite are the main scavengers for trace metals. Furthermore, mineralogical data confirmed more intense weathering occurs on flat terrains compared to undulating hills. Although weathering is intense to extreme for most profiles (Liaghati, Preda and Cox, unpubl. data), gibbsite was not detected in the study area possibly due to insufficient moisture and drainage. The areas, which are more prone to leach metals, are morphologically flat with a shallow water table and mudstone as parent rock. The relative influence of mineralogy, geological setting, and groundwater occurrence and flow on chemical weathering of the sedimentary rocks in this catchment has been found to be: mineralogy > geological setting (topography \& parent rock type $>$ water table depth $>$ depth of profile burial.

\section{ACKNOWLEDGMENTS}

We thank Lensworth Group Ltd. for financial support. We also thank Alan Craig (the Advanced Centre for Queensland University Isotope Research Excellence) for total digestion analysis of trace elements and Hayden McDonald from Mipela for the GIS database. Our colleague Tim Ezzy is acknowledged and thanked for conducting the drilling and addi- tional mapping information. We also wish to thank Bill Kwiecien, Wathsala Kumar, and Tony Raftery for assistance with chemical and mineralogical analyses.

\section{Literature Cited}

Berner, E. K., and R. A. Berner. 1996. Global environment: Water, air and geochemical cycles. Prentice Hall, Englewood Cliffs, New Jersey.

Berner, R. A. 1971. Principles of chemical sedimentology. McGraw-Hill, New York.

Boggs, S. 1995. Principles of sedimentology and stratigraphy. Prentice Hall, Englewood Cliffs, New Jersey.

Calvert, C. S., S. W. Buol, and S. B. Weed. 1980. Mineralogical characteristics and transformations of a vertical rocksaprolite-soil sequence in the North Carolina Piedmont: Feldspar alteration products-their transformation through the profile. Soil Sci. Soc. Am. J. 44:11041112 .

Carroll, D. 1970. Rock weathering. Plenum Press, New York.

Chamley, H. 1989. Clay sedimentology. Springer-Verlag, Berlin.

Chesworth, W., J. Dejou, and P. Larroque. 1981. The weathering of basalt and relative motilities of the major elements at Belbex, France. Geochim. Cosmochim. Acta 45:1235-1243.

Cook, J. M., M. J. Gardner, A. H. Griffiths, M. A. Jessep, J. E. Ravenscroft, and R. Yates. 1997. The comparability of sample digestion techniques for the determination of metals in sediments. Mar. Pollut. Bull. 34 (8): 637-644.

Cramer, J. J., and H. W. Nesbitt. 1983. Massbalance relations and trace element mobility during continental weathering of various igneous rocks. Symp. Petrol. Weather Soils. Sci. Geol. Mem. (Brisbane) 73:6373.

Cranfield, L. C. 1983. Shallow stratigraphic drilling in the Brisbane 1:100,000 sheet area. Record 40. Geological Survey of Queensland.

Eggins, S. M., J. D. Woodhead, L. P. J. Kinsley, G. E. Mortimer, P. Sylvester, M. T. McCulloch, J. M. Hergt, and M. R. Hand- 
ler. 1997. A simple method for the precise determination of $>40$ trace elements in geological samples by ICPMS using enriched isotope internal standardisation. Chem. Geol. 134:311-326.

Evans, L. J. 1992. Alteration products at the earth's surface-the clay minerals. Page 618 in I. P. Martini and W. Chesworth, eds. Weathering, soils and paleosoils. Elsevier, New York.

Exley, C. S. 1976. Observations on the formation of kaolinite in the St. Austell Granite, Cornwall. Clay Miner. 11:51-63.

Ezzy, T. R., and M. E. Cox. 2003. Implications of land-use changes on groundwater within shallow coastal plain aquifers, Bells Creek catchment, Southeast Queensland, Australia. Pages 439-444 in J. A. Lopez-Geta et al., eds. Coastal aquifers intrusion technology: Mediterranean countries: Contribution to our knowledge of the situation concerning marine water intrusion into Mediterranean coastal aquifers. Hidrogeologia y Aguas Subterraneas, No. 8. Instituto Geologico y Minero de Espana, 11-14 March, Alicante, Spain.

Ezzy, T. R., M. E. Cox, and B. Brooke. 2002. The influence of stratigraphy on the occurrence and composition of groundwater within a coastal valley-fill: Meldale, southeastern Queensland. Page 6 in T. Haig, A. Knapton, D. George, and S. Tickell, eds. Balancing the groundwater budget. CD of conference proceedings, International Association of Hydrogeologists Groundwater Conference, 12-17 May, Darwin, Australia.

Ezzy, T. R., A. J. O'Rourke, G. J. Huftile, and M. E. Cox. 2003. Applying ground penetrating radar (GPR) to improve hydrogeological understanding and groundwater modelling within a coastal plain setting. Pages 149-156 in J. A. LopezGeta et al., eds. Coastal aquifers intrusion technology: Mediterranean countries: Contribution to our knowledge of the situation concerning marine water intrusion into Mediterranean coastal aquifers. Hidrogeologia y Aguas Subterraneas, No. 8. Instituto Geologico y Minero de Espana, 11-14 March, Alicante, Spain.

Fields, M., and L. D. Swindale. 1954. Chem- ical weathering of silicates in soil formation. N. Z. J. Sci. Technol. 35:140-154.

Flood, P. G. 1981. Carbon-14 dates from the coastal plains of Deception Bay, southeastern Queensland. Queensl. Gov. Mining J. 82:19-23.

Govindaraju, K. 1994. Compilation of working values and sample description for 383 geostandards. Geostandards Newsl. 18:1158.

Grimes, K. G., L. C. Cranfield, P. J. T. Donchak, L. J. Hutton, and M. R. Jones. 1986. Brisbane, Queensland, Australia. 1:100,000 Geological Series, Sheet 9543. Geological Survey of Queensland, Brisbane.

Harris, R. C., and J. A. S. Adams. 1966. Geochemical and mineralogical studies on the weathering of granitic rocks. Am. J. Sci. 264:146-173.

Hawkins, P. J. 1983. Petrology of sandstone samples from road cuttings, Southeast Queensland, Record 22. Geological Survey of Queensland, Brisbane.

Helgeson, H. C., R. M. Garrels, and F. T. Mackenzie. 1969. Evaluation of irreversible reactions in geochemical processes involving minerals and aqueous solutions II. Applications. Geochim. Cosmochim. Acta. 33:455-481.

Hill, I. G., R. H. Worden, and I. G. Meighan. 2000. Geochemical evolution of a palaeolaterite: The Interbasaltic formation, Northern Ireland. Chem. Geol. 166:65-84.

Hillier, S. 2000. Accurate quantitative analysis of clay and other minerals in sandstones by XRD; comparison of a Rietveld and a reference intensity ratio (RIR) method and the importance of sample preparation. Clay Miner. 35:295-306.

Islam, M. R., S. Rojstaczer, R. Aario, and V. Peuraniemi. 2002. Mineralogical changes during intense chemical weathering of sedimentary rocks in Bangladesh. J. Asian Earth Sci. 20:889-901.

International Organization for Standardization. 1995. Soil quality, extraction of trace elements soluble in Aqua Regia. ISO 11466. Geneva, Switzerland.

Jenny, H. 1941. Factors in soil formation. McGraw-Hill, New York.

Kaschl, A., V. Romheld, and Y. Chen. 2002. 
The influence of soluble organic matter from municipal solid waste compost on trace meal leaching in calcareous soils. Sci. Total Environ. 291:45-57.

Lester, J., B. Brooke, and M. E. Cox. 2000. An assessment of the stability of the Bribie Island spit based on studies of geomorphology, sedimentology and shoreline processes. Pages 19-21 in M. E. Cox, ed. Proceedings of the Pumicestone Conference, PASSCON 2000, 22-23 November, Queensland University of Technology, Brisbane, Australia.

Lodding, W. 1972. Conditions for the direct formation of gibbsite from K-feldspar. Am. Miner. 57:292-294.

Loughnan, F. C. 1969. Chemical weathering of silicate minerals. American Elsevier Publishing Company, New York.

Macias, F., and W. Chesworth. 1992. Weathering in humid regions, with emphasis on igneous rocks and their metamorphic equivalents. Page 618 in I. P. Martini and W. Chesworth, eds. Weathering, soils and paleosols. Elsevier, New York.

McCaleb, S. B. 1959. The genesis of redyellow podzolic soils. Soil Sci. Soc. Am. Proc. 23:164-168.

Mozley, P. S., and P. Wersin. 1992. Isotopic composition of siderite as an indicator of depositional environment. Geology 20:817-820.

Murphy, P. R., D. L. Trezise, L. J. Hutton, and L. C. Cranfield. 1987. 1:100,000 Geological Map Commentary. Caboolture, Sheet 9443, Queensland. Department of Mines, Geological Survey of Queensland, Brisbane.

NSR Environmental Consultants. 1999. Caloundra downs informal land use investigation: Consolidated data report, main volume. Report prepared for Lensworth Group, Ltd., Brisbane, Queensland.

Parham, W. E. 1969. Formation of halloysite from feldspar: Low temperature artificial weathering versus natural weathering. Clays Clay Miner. 17:13-22.

Preda, M., and M. E. Cox. 2002. Trace metals occurrence and distribution in sediments and mangroves, Pumicestone Region, Southeast Queensland, Australia. Environ. Int. 28:433-449.
. 2004. Temporal variations of mineral character of acid-producing pyritic coastal sediments, Southeast Queensland, Australia. Sci. Total Environ. 326:257-269.

Richards, B. K., T. S. Steenhuis, J. H. Peverly, and M. B. McBride. 2000. Effect of sludge-processing mode, soil texture and soil $\mathrm{pH}$ on metal mobility in undisturbed soil columns under accelerated loading. Environ. Pollut. 109:327-346.

Summerfield, M. A. 1991. Global geomorphology. John Wiley and Sons, New York.

Tam, N. F. Y., and M. W. Y. Yao. 1998. Normalization and heavy metal contamination in mangrove sediments. Sci. Total Environ. 216:33-39.

Taylor, K. G. 1998. Spatial and temporal variations in early diagenetic organic matter oxidation pathways in Lower Jurassic mudstones of eastern England. Chem. Geol. 145:47-60.

Taylor, K. G., and R. G. Eggleton. 2001. Regolith geology and geomorphology. John Wiley and Sons, New York.

Thomas, M. F. 1994. Geomorphology in the tropics: A study of weathering and denudation in low latitude. John Wiley and Sons, Chichester, England.

Udom, B. E., J. S. C. Mbagwu, J. K. Adesodun, and N. N. Agbim. 2004. Distribution of zinc, copper, cadmium and lead in a tropical ultisol after long term disposal of sewage sludge. Environ. Int. 30:467-470.

Uysal, I. T., S. D. Golding, and M. Glikson. 2000. Petrographic and isotope constraints on the origin of authigenic carbonate minerals and the associated fluid evolution in Late Permian coal measures, Bowen Basin (Queensland), Australia. Sediment. Geol. 136:189-206.

Welch, S. A., and D. C. McPhail. 2003. Mobility of major and trace elements during biologically mediated weathering of granite. Pages 437-440 in I. C. Roach, ed. Advances in regolith. The Cooperative Research Centre for Landscape Environments and Mineral Exploration, Perth, Western Australia.

Williams, M., D. Dunkerley, P. De Deckker, P. Kershaw, and J. Chappell. 1998. Quaternary environments. Arnold, Hodder Headline Group, London. 